Agro-Science Journal of Tropical Agriculture, Food, Environment and Extension Volume 15 Number 3 (September 2016) pp. 7 - 12

ISSN 1119-7455

\title{
LABOUR PRODUCTIVITY AND RESOURCE USE EFFICIENCY AMONGST SMALLHOLDER COCOA FARMERS IN ABIA STATE, NIGERIA
}

\author{
Obike, K.C., Idu, M.A. and Aigbokie, S.O. \\ Department of Agricultural Economics, Michael Okpara University of Agriculture, Umudike, \\ PMB 7267 Umuahia, Abia State, Nigeria
}

\begin{abstract}
The study examined labour productivity and resource efficiency amongst smallholder cocoa farmers in Abia State, Nigeria. A purposive random sampling technique was adopted in selecting 60 cocoa farmers from three agricultural zones in the State. The analytical techniques used involve inferential statistics like means, frequency and percentages. Loglinear regression analysis was also used. The results show that factors influencing labour productivity among cocoa farmers include level of education, experience and planting material. Also, the determinants of output among cocoa farmers revealed that planting materials, fertilizer use and capital were significant determinants of output among cocoa farmers in the study area. The determinants of allocative efficiency show that seed was under-utilized, while farm size, labour, fertilizer and capital were over-utilized. The results further revealed that poor farm wages (labour payments) ranked highest (38.3\%) among labour inhibitor in the study area. It is therefore recommended that supply of adequate capital in terms of productivity should form a policy trust in agriculture; adequate policy that would encourage provision of capital to cocoa farmers is advocated. The farmers should be encouraged to utilize their family labour efficiently in order to reduce use of hired labour which has led to increase in the cost of food crops production and decrease in farm revenue.
\end{abstract}

Key words: labour productivity, allocative efficiency, resource use, cocoa farmers, Abia State

\section{INTRODUCTION}

Analysis of efficiency is generally associated with the possibility of farms producing a certain optimal level of output from a given bundle of resources or certain level of output at least cost. There are two approaches to it: parametric and non-parametric. The parametric approach relies on a parametric specification of the production function; the nonparametric approach has the advantage of imposing non apriori parametric restriction to the underlying technology (Adewuyi and Okunmadewa, 2001). Allocative efficiency has to do with the extent to which farmers make efficient decision such that inputs are used up to a level at which their marginal contribution value is equal to the factor cost. It is defined as the choice of the optimal input proportions given relative prices (Omonona et al., 2010).

An increase in efficiency in crop production could present a ray of hope and could lead to an improvement in the welfare of the farmer and consequently a reduction in their poverty level and food insecurity. Low yields are as a result of inefficient production techniques manifested in technical and allocative inefficiencies, overreliance on household resources, labour-intensive agricultural technology and rapidly declining soil productivity (Amaze and Manrice, 2005). The farm-level efficiency of smallholder resources has important implications for the agricultural development of a nation. Efficient farms make better use of existing resources and produce their output at the lowest cost (Amaze and Manrice, 2005, Sunday et al., 2014).

The term labour productivity is quantitatively determined by comparing labour cost with the total efficiency of labour, which is usually depicted by the amount of produced products. In the literature, the term is sometimes used to express the productivity of labour and in other times the total profitability of the coefficients and production factors. More broadly defined, productivity refers to production processes and is quantitatively expressed as the quantity of produced goods (output) divided by the units of the production coefficients used (input) (Polyzos, 2003). Human labour is about the only main source of labour available to small-holder farmers in Nigeria. Smallholder farmers contribute over $85 \%$ of domestic agricultural output in Nigeria (Gocowski, 2003). Okuneye (2000) noted that hired labour contributes $88 \%$ of the total labour use on farms thus highlighting its role in agriculture. Family labour and exchange labour could also be employed. Again, the seasonal relationship between the periodical changes in labour cost reduction, use patterns and different labour operations meant to be 
timely performed exert a limit to the proportion of household labour that can be depended upon. Nearly all farm works are concentrated in the wet season. A slight delay will be costly, particularly at very short wet season. At such times, demand for labour becomes most alarming.

Cocoa, botanically known as Theobroma cacao belongs to the family Stericulinacea. It originated from the upper Amazon region of the South America from where it spread to different parts of the world (Osun, 2001). According to Microsoft Encarta (2009) cocoa has a high food value, containing as much as $20 \%$ protein, $40 \%$ carbohydrate, and $40 \%$ fat. It is also mildly stimulating because of the presence of bromine, an alkaloid that is closely related to caffeine. The beans are sold in international markets. African countries harvest about two-thirds of the total world output; Ghana, Côte d'Ivoire, Nigeria, and Cameroon are the leading African cocoa producers. Most of the remainder comes from South American countries, chiefly Brazil and Ecuador. The crop is traded on international commodity futures markets. Attempts by producing countries to stabilize prices through international agreements have had little success. It is worth noting that the world cocoa production is on the scale of 3 million tons and Ondo state is the largest cocoa-producing state in Nigeria (Amos and Adeleke, 2010).

\section{MATERIAL AND METHODS}

\section{Study Area}

The study was conducted in Abia State. Abia State was created out of Imo State on August 27, 1991. It has a land mass of 700 square $\mathrm{km}$. The state lies between longitudes $7^{\circ} 23^{\prime}$ and $8^{\circ} 02^{\prime}$ East of Greenwich meridian and latitudes $5^{\circ} 49^{\prime}$ and $6^{\circ} 12^{\prime}$ North of the equator. Abia State is bounded on the east by the Cross River and Akwa Ibom States, on the north by Ebonyi and Enugu States, on the West by Imo State and on the South by Rivers State. According to the National Population Commission, Abia State is populated by $1,904,908$ persons made up of 933,030 males and 971,878 females (NPC, 1999). With estimated annual population growth rate of $2 \%$, the present population is about $2,368,574$ consisting of $1,160,141$ males and $1,208,433$ females. This population consists of people in all walks of life with about $65 \%$ of their engagement being in agriculture (ASPC, 2008). Farming is done at subsistence level. The women only farm on their husbands' land as they do not have direct title to land. The state is endowed with a rich fertile soil that supports the growth of crops; yam, cassava, cocoyam, melon, maize, oil palm, garden egg, cocoa, to mention but a few. Poultry, goat, pigs and sheep are the major livestock kept. Abia State has 17 local government areas (LGAs). These are grouped into three agricultural zones namely Aba, Umuahia and Ohafia zones.

\section{Sampling Techniques}

The population of this study consists of cocoa farmers in Umuahia and Ohafia agricultural zones of Abia State. A purposive sampling technique was used in choosing the sample. In the first stage, two agricultural zones in the state were purposively selected namely Umuahia and Ohafia zones. Secondly, in Umuahia zone, two LGAs were selected namely Umuahia and Ikwuano, while in Ohafia zone, Bende LGA was purposively chosen. The third stage involved selection of one community from the three LGAs. In the last stage, 20 cocoa farmers were selected from each of the selected communities. This gave a total of 60 respondents for the study.

\section{Data Collection}

The study used only primary data sources. The primary data were obtained through aid of questionnaire and interview schedule. Additionally, personal observations also formed a critical means of data collection. Information collected included data on the socio-economic characteristics, the sources, labour-use types and periods of labour needs in cocoa production, the costs and returns associated with cocoa production, minimum amount of labour required to produce a given level of output, labour-use efficiency and determinants of labour-use efficiency in cocoa production, perceived labour cost reduction strategies in the study area and the factors constraining farmers labour supply in the study area.

\section{Method of Analysis}

Both descriptive and inferential statistics were used to analyze data. Determinants of labour productivity of the cocoa farmers were estimated using Ukoha's (2000) method. The log-linear model derived from Cobb Douglas functional form was the econometric model specified for explaining labour productivity, as did Ukoha (2000) for cocoyam productivity. This functional form is the most popular in applied research because it is easier to handle mathematically. The model is described thus:

$$
\mathrm{Y} / \mathrm{N}=f(\mathrm{AGE}, \mathrm{HHS}, \mathrm{EDU}, \mathrm{EXP}, \mathrm{FARS}, \mathrm{SEED}, \mathrm{CAP}) \text {; }
$$

where $\mathrm{Y} / \mathrm{N}$ is labour productivity ( $\mathrm{kg} /$ manday); i.e., $Y$ is cocoa output in $\mathrm{kg}$ while $N$ is labour input for all activities in mandays; AGE is age (years); HHS is household size; EDU is farmers' level of education (years); EXP is farming experience (years); FARS is farm size (hectares); SEED is cocoa seed planted $(\mathrm{kg})$; and CAP is capital (Naira).

Multiple regression model was used to analyze the determinants of output of the cocoa farmers:

$$
\mathrm{Y}=f\left(\mathrm{X}_{1}, \mathrm{X} 2, \mathrm{X} 3, \mathrm{X} 4, \mathrm{X} 5, \mathrm{e}\right) \text {; }
$$

where $Y$ is value of output of famers, $X_{1}$ is total area of farmland under cultivation (hectares), $X_{2}$ is labour input in mandays, $X_{3}$ is seed cost (Naira), $X_{4}$ 
is fertilizer input $(\mathrm{kg}), X_{5}$ is capital input in (Naira) (which includes depreciation of farm tools and equipment, machinery, etc.; interest charges on borrowed capital; repair and maintenance costs; etc.), and $e$ is error term.

The allocative efficiency of the cocoa farmers was obtained from the estimated equation by comparing the Marginal Value Product (MVP) of a given input with its Marginal Factor Cost (MFC). The MVP and MFC for an input were obtained as:

$$
\begin{aligned}
& \mathrm{MVP}_{\mathrm{xi}}=\mathrm{MPP}_{\mathrm{xi}} \times \mathrm{p} \text {, and } \\
& \mathrm{MFC}_{\mathrm{xi}}=\mathrm{MPP}_{\mathrm{xi}} \times \text { rxirxi; }
\end{aligned}
$$

where $\mathrm{MPP}_{\mathrm{xi}}$ is the Marginal Physical Product of $\mathrm{xi}, p$ is the unit price of the output (Q), and rxirxi is price of the input used.

\section{RESULTS AND DISCUSSION}

\section{Socio-Economic Characteristics of Respondents}

The data in Table 1 show that the mean age was 39 years. Nwaru and Ekwumankama (2002) reported mean ages of 42 and 49 years for men and women crop farmers, respectively. The implication of this age bracket on productivity is increased production and likelihood of poverty reduction in the area. However the result shows that majority of the respondents were adults, matured, energetic and enterprising. This represents an active stage in life. Majority (56.67\%) of the respondents were males. These results agree with the findings in most studies carried out in the south-eastern region of the country (Iheke, 2006; Ogbe, 2009). Furthermore, $6.67 \%$ of the respondents were single, $91.67 \%$ were married, and $1.67 \%$ was separated. The implication is that there are more stable households which are better positioned to practice agriculture. This implies that a greater percentage of the farmers had family members. According to Nwaru (2004), such stability creates conducive environment for good citizen training, development of personal integrity and entrepreneurship, which are very important for efficient uses of resources.

An overwhelming majority $(96.7 \%)$ of the respondents have formal education, with mean farming experience of 14 years in farming. This is desirable because according to Obasi (1991), the level of education of a farmer not only increases his farm productivity but also enhances his ability to understand and evaluate new production techniques. The implication is that the respondents are better positioned to take advantage of new technique and innovation that could improve agricultural productivity and boost food security. Imburr et al. (2008) reported that improved education level brings about positive changes in the knowledge, attitude and skills through research and extension. Results further show that $70.0,26.67$ and $3.33 \%$ of the respondents had a household size of 1-4, 5-8, and 9-12 persons, respectively. The mean household was four persons. This is desirable, consistent and of great importance in farm production as rural household may rely more on their members than hired workers for labour on their farms. This is so if members are not made up of the aged and very young people, otherwise scarce capital resources that should have been employed for farm production would be channeled for upkeep of these dependent members (Nwaru, 2004). Also the mean hectare cultivated is 2.33. This further indicates that a greater percentage of the respondents in the study area had above 1.01 hectare of land under cultivation or active farm operations.

Labour Source and Use by Some Farm Activities Table 2 shows the labour-use portfolio of the cocoa farmers of the study. The data show that the farmers appreciably make use of share cropper labour option in cocoa farming. This notion emanates from the general perception that share croppers are honest and dedicated in the discharge of their duties on the farms. This invariably enhances the level of productivity and accruable profit (Akanni and Dada, 2012).

Table 1: Distribution of respondents according to

\begin{tabular}{|c|c|c|}
\hline Variables & Frequency & Percentage \\
\hline \multicolumn{3}{|l|}{ Sex } \\
\hline Female & 26 & 43.33 \\
\hline Male & 34 & 56.67 \\
\hline \multicolumn{3}{|l|}{ Age (years) } \\
\hline $21-30$ & 17 & 28.33 \\
\hline $31-40$ & 17 & 28.33 \\
\hline $41-50$ & 16 & 26.67 \\
\hline $51-60$ & 6 & 10.00 \\
\hline $61-70$ & 4 & 6.67 \\
\hline Mean & 39 & \\
\hline \multicolumn{3}{|l|}{ Marital Status } \\
\hline Single & 4 & 6.67 \\
\hline Married & 55 & 91.67 \\
\hline Separated & 1 & 1.67 \\
\hline \multicolumn{3}{|l|}{ Level of Education } \\
\hline Never attended & 2 & 3.32 \\
\hline Primary education & 6 & 10.00 \\
\hline Secondary education & 48 & 80.00 \\
\hline Tertiary education & 6 & 6.67 \\
\hline \multicolumn{3}{|l|}{ Household size } \\
\hline $1-4$ & 42 & 70.00 \\
\hline $5-8$ & 16 & 26.67 \\
\hline $9-12$ & 2 & 3.33 \\
\hline Mean & 4 & \\
\hline \multicolumn{3}{|l|}{ Income ( } \\
\hline $0.1-1.0$ & 15 & 25.00 \\
\hline $1.1-2.0$ & 9 & 15.00 \\
\hline $2.1-3.0$ & 16 & 26.67 \\
\hline $3.1-4.0$ & 20 & 33.33 \\
\hline Mean & 2.33 & \\
\hline \multicolumn{3}{|l|}{ Experience(Years) } \\
\hline $1-10$ & 25 & 41.67 \\
\hline $11-20$ & 17 & 28.33 \\
\hline $21-30$ & 18 & 30.0 \\
\hline Mean & 14 & \\
\hline Total & 60 & 100.0 \\
\hline
\end{tabular}
socio-economic characteristics $(n=60)$ 
Table 2: Distribution of the respondents based on source of labour

\begin{tabular}{lcc}
\hline Labour types & Frequency & Percentage \\
\hline Family labour & 15 & 25.0 \\
Hired labour & 13 & 21.67 \\
Exchange labour & 5 & 8.30 \\
Casual labour & 9 & 15.0 \\
Share cropping & 18 & 30.0 \\
Total & 60 & 100.0 \\
\hline
\end{tabular}

Source: Field Survey, 2016

Allocation of labour usually varies with farming activities. While some tasks require skilled hired labour, household/family labour is sufficient for some. The cost and availability may preclude the use of hired labour of different classes for such activities as under-storey clearing, agrochemical spraying, pod harvesting and fertilizer application which are the most labour intensive operations in cocoa production.

Table 3 presents the use of labour by specific activities in the study area. The use of labour was minimal for under-storey clearing and fertilizer application. This corroborates the finding of Gocowski (2003) that slashing of vegetative under storey growth in cocoa farms was done just twice in a year prior to the harvesting season while fruiting fertilizers were applied once throughout a productive season. Labour was engaged more on agrochemical spraying and cocoa harvesting with the averages of 35 and $30 \%$, respectively.

Log-linear result of the determinant of labour productivity among cocoa farmers are summarized and presented in Table 4. The coefficient of multiple determination was 0.892 which implies that $89.2 \%$ of the variation in the farmers output was explained by the explanatory variable. Level of education, experience and farm size were significant. The level of education had significant $(p<0.01)$ positive relationship with labour productivity of the cocoa farmers. This implies that as the cocoa farmers attain higher level of education, their labour productivity increases. Better education has the effect of enabling household's conceptualized information on improved farming methods and other related issues capable of enhancing their labour productivity. This is desirable because the level of education of a farmer not only increases his farm productivity but also enhances his ability to understand and evaluate new production techniques (Obasi, 1991). Farming experience had significant $(p<0.05)$ positive relationship with the labour productivity of the farmer. Thus, as the experience of the farmer increases, his labour productivity also increases. Increase in farming experience raises human knowledge and skill to adapt to new farming techniques which increase their efficiency of production (Nwaru, 2004). The coefficient of the relationship of farm size to labour productivity is significant $(p<0.01)$ and negative. This implies that the more the land for under cocoa production the greater the lowering of the labour productivity.

\section{Determinants of output of the Cocoa Farmers}

The multiple regression results are summarized and presented in Table 5. The coefficient of multiple determination was 0.881 which implies that $88.1 \%$ of the variation in the farmers output was explained by the explanatory variable. Planting materials (seeds) was significant $(p<0.01)$ positively related to output, implying that as planting materials (seeds) increase, output increases and vice versa. This implies that use of yield increasing seed is sine-qua-non to increase the cocoa farmers output. The fertilizer use was significantly $(p<0.05)$ positively related; this implies that an increase in fertilizer use leads to significant improvement in the output level of the farmer. This corroborates the findings of Mban and Edeh (2011) that fertilizer use and farm productivity were positively related. Capital was also negatively related to the level of output. This indicates that an increase in capital (farm tools) in cocoa production leads to a decrease in the output levels of the farmers.

Table 3: Distribution of respondents based on labour-use by specific farm activities

\begin{tabular}{lcc}
\hline Labour- se & Frequency & Percentage \\
\hline Under-storey clearing & 11 & 18.33 \\
Agrochemical spraying & 21 & 35.00 \\
Harvesting & 18 & 30.00 \\
Fertilizer application & 10 & 16.67 \\
Total & 60 & 100.0 \\
\hline
\end{tabular}

Source: Field Survey, 2016

Table 4: Log-linear regression result on determinants of labour productivity of the cocoa farmers

\begin{tabular}{lcc}
\hline Variables & Log-linear & Percentage \\
\hline Intercept & $4.447(6.322)^{* *}$ & 18.33 \\
Age $\left(\mathrm{X}_{1}\right)$ & $0.023(0.364)$ & 35.00 \\
household size. $\left(\mathrm{X}_{2}\right)$ & $0.014(0.422)$ & 30.00 \\
Level of education $\left(\mathrm{X}_{3}\right)$ & $0.809(14.308)^{* *}$ & 16.67 \\
farming experience $\left(\mathrm{X}_{4}\right)$ & $0.159(2.169)^{*}$ & 100.0 \\
farm size $\left(\mathrm{X}_{5}\right)$ & $-0.052(-1.888) \dagger$ & \\
Planting materials $\left(\mathrm{X}_{6}\right)$ & $-0.029(-1.149)$ & \\
capital $\left(\mathrm{X}_{7}\right)$ & $0.054(1.906)$ & \\
$\mathrm{R}^{2}$ & 0.892 & \\
$\mathrm{R}^{-2}$ & 0.877 & \\
F-ratio & $61.240^{* *}$ & \\
\hline
\end{tabular}

Source: Field Survey, 2016. Figures in parenthesis are t-values. **significant at $1 \%$, *significant at $5 \%$, † significant at $10 \%$.

Table 5: Multiple regression result on output of the cocoa farmers

\begin{tabular}{lc}
\hline Variables & Double log+ \\
\hline Intercept & $4.449(7.083)^{* * *}$ \\
Farm size $\left(\mathrm{X}_{1}\right)$ & $0.050(0.795)$ \\
Labour $\left(\mathrm{X}_{2}\right)$ & $0.002(0.046)$ \\
Seed $\left(\mathrm{X}_{3}\right)$ & $0.783(14.057)^{* * *}$ \\
Fertilizer $\left(\mathrm{X}_{4}\right)$ & $0.178(2.371)^{* *}$ \\
Capital $\left(\mathrm{X}_{5}\right)$ & $-0.050(-1.795)^{*}$ \\
$\mathrm{R}^{2}$ & 0.881 \\
$\mathrm{R}^{-2}$ & 0.870 \\
F-ratio & $79.784 * * *$ \\
\hline
\end{tabular}

Source: Field Survey, 2016

+lead equation. Figures in parenthesis are t-values.

**significant at $1 \%$, * significant at $5 \%$, † significant at $10 \%$. 
Table 6: Determinants of resource use efficiency

\begin{tabular}{lccccc}
\hline Variables & MPP & MVP & MFC & Efficiency ratio & Efficiency level \\
\hline Farm size & 0.050 & 812.5 & 4000 & 0.203 & Over utilized \\
Seed & 0.783 & 12723.8 & 3308.3 & 3.85 & Underutilized \\
Labour & 0.002 & 32.5 & 6406.7 & 0.006 & Over utilized \\
Fertilizer & 0.178 & 2892.5 & 6250 & 0.463 & Over utilized \\
Capital & -0.050 & -812.5 & 6086.77 & -0.133 & Over utilized \\
\hline Source: Field Survey, 2016 & & & &
\end{tabular}

Source: Field Survey, 2016

Table 7: Distribution of respondents based on cocoa labour supply inhibitor in the Abia State

\begin{tabular}{lcc}
\hline Inhibitor & Frequency & Percentage \\
\hline Labour payment & 23 & 38.3 \\
Seasonal migration & 11 & 18.3 \\
Schooling of children & 10 & 16.7 \\
Non-availability of adults & 4 & 6.7 \\
Improved non-farm Income & 12 & 20.0 \\
Total & 60 & 100.0 \\
\hline
\end{tabular}

Source: Field Survey, 2016

\begin{abstract}
Allocative Efficiency amongst the Cocoa Farmers The determinants of allocative efficiency among the cocoa farmers are presented in Table 6. The results show the ratio of the marginal value product (MVP) to the marginal factor cost (MFC) for farm size, seed, labours, fertilizer and capital. Seed was under-utilized, meaning that farmers would earn higher returns from their production if they increase the use of these inputs while holding other inputs constant. Farm size, labour, fertilizer and capital were over-utilized, implying that a decrease in these inputs would, holding other input constant, increase the productivity level.
\end{abstract}

\section{Cocoa labour supply inhibitor in Abia State}

Table 7 shows the distribution of various causes of constraints to labour supply in cocoa plantations in the study area. Poor farm wages (labour payments) ranked as the highest labour inhibitor in the study area, followed by improved non-farm income. Seasonal migration, of labour to the urban sector in search of promising non-farm employment activities, the schooling of children and nonavailability of adults to supply labour were other labour inhibitors in the area.

\section{CONCLUSION/RECOMMENDATIONS}

Based on the findings of this study, it is concluded that level of education, experience and farm size were determinants of labour productivity while planting materials, fertilizer use and capital were significant determinants of output among cocoa farmers. Also, planting material (seed) was underutilized, meaning farmers will earn higher return from their production if they increase the use of these inputs while holding other input constant. Farm size, labour, fertilizer and capital were overutilized; this implies that a decrease in these inputs holding other inputs constant would increase the productivity level. The farmers should utilize their family labour efficiently in order to reduce the hired labour that increases the cost of food crops production and decreases farm revenue.

\section{REFERENCES}

Adewuyi, S.A. and Okunmadewa, F.Y. (2001). Economic efficiency of crop farmers in Kwara State, Nigeria. Nigerian Agric. Development Studies, 2 (1), 45-57

Amaze, P.S. and Manrice, D.C. (2005). Identification of factors that influence technical efficiency in rice based production systems in Nigeria. Paper presented at Workshop on Policies And Strategies For Promoting Rice Production and Food Security in Sub-Saharan African, Colonou, Benin

Amos, T.T. and Manrice, D.C. (2005). Strategies towards adaptation to the effects of climate change on cocoa production in Ondo State, Nigeria. In: Nmadu J.N., Ojo M.A., Mohammed U.S., Baba K.M., Ibrahim F.D. and Yisa E.S. (eds.). Commercial Agriculture, Banking Reform and Economic Downturn: Setting a New Agenda for Agricultural Development in Nigeria. Proceedings of 11th Annual National Conference of National Association of Agricultural Economists (NAAE) held at Federal University of Technology, GidanKwano, Minna, 30th November -3rd December, 2005, pp. 366-368

Gocowski, J. and Oduwole, S. (2003). Labour practices in the cocoa sector of Southwest Nigeria with a special focus on the role of children. STCP/IITA Monograph IITA, Ibadan, Nigeria, pp. 17-21

Iheke, R.O. (2006). Gender and resource use efficiency in rice production system in Abia State, Nigeria. MSc Thesis, Department of Agricultural Economics, Michael Okpara University of Agriculture, Umudike, Nigeria

Imbur, E.N., Agwu, A.E., and Akinnagbe, O.M. (2008) Adoption of citrus production technology among farmers in Kastina-Ala Local Government Area, Benue State, Nigeria. Journal of Agriculture Extension, 11, 14-27

Akanni, K.A. and Dada, A.O. (2012) Analysis of labour use patterns among small-holder cocoa farmers in South Western Nigeria. Journal of Agricultural Science and Technology B 2: 107-113

Mbam, B.N. and Edeh, H.O. (2011). Determinants of farm productivity among smallholder rice farmers in Anambra State, Nigeria. Journal of Animal \& Plant Sciences, 9 (3), 1187-1191

Microsoft Encarta (2009). Cocoa. Microsoft ${ }^{\circledR}$ Encarta ${ }^{\circledR}$ 2009 [DVD]. Redmond, WA: Microsoft Corp.

Amos, T.T. (2007). An Analysis of productivity and technical efficiency of small holder cocoa farmers in Nigeria. Journal of Social Sciences, 15(2), 127-133

NPC (2006). Preliminary 2006 census figures. National Population Commission, Nigeria. Retrieved Sept. 2007 from: http://www.population.gov.ng/pop-figure PDF

Nwaru, J.C. and Ekwumankama, O.O. (2002). Economics of resource use by women arable crop farmers in Abia State. Research Report Submitted to the Senate Grant Committee, Michael Okpara University of Agriculture, Umudike, p. 40 
Nwaru, J.C. (2004). Rural Credit Market and Arable Crop Production in Imo State of Nigeria. PhD Dissertation, Michael Okpara University of Agriculture Umudike, Nigeria

Obasi, P.C. (1991). Resource Use Efficiency in Food Crop Production: A Case Study of the Owerri Agricultural Zone of Imo State, Nigeria. MSc Thesis, University of Ibadan, Ibadan Nigeria. pp. 32-36

Ogbe, S.E. (2009). Determinants of Credits Demands and Microfinance Outreach to Farmers in Abia State: A Case Study of National Special Programme on Food Security. MSc Thesis, Michael Okpara University of Agriculture, Umudike, Nigeria

Okuneye, P.A. (2000). Employment generating potentials of agricultural processing and storage technology: additional gain in increased food availability pursuit. Presented at the Workshop for Local Government Officials in Lagos State, 2000, pp. 3-9

Omonona, B.T., Egbetokun, O.A., and Akanbi, A.T. (2010). Farmers resource-use and technical efficiency in cowpea production in Nigeria. Economic Analysis and Policy, 40 (1), 87-95
Osun, T. (2001). Analysis of Socio-Economic factors Affecting Cocoa Production in Ondo State: Case Study of Idanre and Ondo East Local Government Areas. BSc Thesis, Department of Agricultural Economics, Ondo State University, Akure

Polyzos, S., (2003). The productivity of labor and the spatial economic inequalities. Review of Working Relations, 25, 29-49 (in Greek)

Sunday, O.A., Okezie, C.A., and Onyenkazi, H.A. (2014). Determinants of Productivity among Smallholder Rice Farmers in Bende Local Government Area of Abia State, Nigeria. International Journal of Applied Research and Technology, 3 (6), 3-8

Ukoha, O.O. (2000). Determinants of labour productivity on small-holder sole crop farms: a case of waterleaf enterprise (Talinum triangulare). Nigerian Journal of Agribusiness Rural Development, 1: 3 